\title{
Influence of Chemical Reaction, Magnetic Field and Radiation on Heat and Mass Transfer by Free Convection Flow near the Lower Stagnation Point of an Isothermal Horizontal Circular Cylinder in a Porous Medium Considering Soret and Dufour Effects
}

\author{
Bishwa Ram Sharma \\ Department of Mathematics, \\ Dibrugarh University, \\ Dibrugarh-786004, \\ Assam, India
}

\author{
Animesh Aich \\ Department of Mathematics, \\ Dibrugarh University, \\ Dibrugarh-786004, \\ Assam, India
}

\begin{abstract}
Heat and mass transfer characteristics of free convection flow near the lower stagnation point of an isothermal horizontal circular cylinder embedded in a porous medium subjected to chemical reaction, magnetic field and radiation is investigated numerically by taking into account the Soret and Dufour effects using Darcy-Forchheimer model. The concentration profile is drawn for various values of variable viscosity parameter, variable thermal conductivity parameter, radiation parameter, magnetic parameter, porosity parameter, Forchhiemer inertial porous parameter, Prandtl number, Schmidt number, chemical reaction parameter, Soret and Dufour numbers and the results are depicted graphically. Numerical results of rate of mass transfer for different parameters are presented in tabular form.
\end{abstract}

\section{Keywords}

Heat and Mass Transfer, Free Convection, Porous Medium, Isothermal Horizontal Circular Cylinder, Radiation Effect, Porosity Effect, Variable Thermal Conductivity, Variable Viscosity, Magnetic Field, Soret and Dufour effects, Chemical Reaction, Darcy-Forchheimer model.

\section{INTRODUCTION}

Convective flow through porous media has attracted considerable attention in last several decades due to its many important engineering, environmental and geophysical applications. In recent years, MHD flow, heat and mass transfer about cylindrical bodies have attracted many researchers owing to the fact that cylindrical shaped bodies have been used in nuclear waste disposal, space science, energy extortion in underground and catalytic beds. The combined heat and mass transfer problems with chemical reactions have received a considerable amount of attention in recent years. Hossain and Rees [1] studied the natural convection of fluid with temperature dependent viscosity from heated vertical wavy surface. Nazar [2] studied the free convection boundary layer on an isothermal horizontal circular cylinder in a micropolar fluid. Hossain and Pop [3] studied the radiation-conduction interaction on mixed convection past a horizontal cylinder. Kafoussius [4] studied the combined free and forced convection laminar boundary layer past a vertical isothermal flat plate with temperature dependent viscosity. Mehta and Sood [5] studied the transient free convection flow with temperature dependent viscosity in a fluid saturated porous media. Harris [6] studied the transient free convection near the lower stagnation point of a cylindrical surface subjected to a sudden change in surface temperature. Effect of aligned magnetic field on steady viscous flow past a circular cylinder was studied by Sekhar and Sivakumar [7]. Merkin [8] studied the effect of mixed convection boundary layer on an isothermal horizontal circular cylinder. Molla and Hossain [9] studied the natural convection flow from an isothermal horizontal circular cylinder with temperature dependent viscosity. The combined heat and mass transfer along a vertical moving cylinder with a free stream was studied by Takhar and Chamka [10]. In this analysis both uniform wall temperature and uniform heat flux cases have been included. Bhargava [11] found the finite element solution for non-newtonian pulsatile flow in a nondarcian porous medium conduit using the Darcy-Forchhiemer model. Transient analysis of heat and mass transfer by natural convection in power law fluid past a vertical plate immersed in a porous medium is studied by Elgazery [12]. Many processes in engineering areas occur in high temperature and consequently the radiation plays a significant role. Rashad [13] studied the perturbation analysis of radiative effect on free convection flow in the presence of pressure work and viscous dissipation. He used the Rosseland approximation to incorporate the effect of radiation, in the mathematical model of the problem.. Deka and Paul [14] discussed the transient free convective flow past an infinite vertical cylinder with heat and mass transfer. Ganeswar Reddy and Bhaskar Reddy [15] investigated the thermal radiation and mass transfer effects on an unsteady MHD free convective flow of an incompressible viscous fluid past a moving vertical cylinder . Yih [16] discussed the radiation effect on natural convection over a vertical cylinder embedded in a porous media. Chamkha and Ben-Nakhi [17] investigated the MHD mixed convection-radiation interaction along a permeable surface immersed in a porous medium in the presence of Soret and Dufour's effects. Kandasamy [18] discussed chemical reaction, heat and mass transfer on MHD flow over a vertical stretching surface with heat source and thermal stratification effects. Sharma and Nath [19] discussed the effects of heat generation, thermal diffusion, magnetic field and chemical reaction by considering a vertical isothermal permeable cylinder moving with a linear velocity in the fluid mixture infinite in extent. Ibrahim [20] discussed the effect of the chemical reaction and radiation absorption on the unsteady MHD free convection flow past a semi infinite vertical permeable moving plate with heat source and suction. Sharma 
and konwar [21] investigated the MHD flow, heat and mass transfer due to axially moving cylinder in presence of thermal diffusion, radiation and chemical reactions in a binary fluid mixture. Ziyauddin and Kumar [22] studied the MHD heat and mass transfer free convection flow near the lower stagnation point of an isothermal Cylinder imbedded in Porous Domain with the presence of Radiation. Elkabeir [23] studied the Soret and Dufour effects on heat and mass transfer due to a stretching cylinder saturated porous medium with chemically-reactive species.

The objective of this paper is to study the effect of chemical reaction, Radiation, thermal-diffusion and diffusion-thermo effects on MHD heat and mass transfer free convection flow near the lower stagnation point of an isothermal horizontal circular cylinder in a Porous medium.

\section{MATHEMATICALFORMULATION}

A steady laminar two-dimensional MHD free convection flow together with heat and mass transfer of a viscous, incompressible, electrically conducting fluid absorbing-emitting radiations over a uniformly heated circular cylinder of radius ' $r$ ' in a porous medium is considered. The surface of the cylinder is maintained at a constant temperature $T_{w}$ and a constant concentration $C_{w}$. The ambient temperature and concentration far away from the surface of the cylinder is $T_{\infty}$ and $C_{\infty}$ respectively where $T_{w}>T_{\infty}$ and $C_{w}>C_{\infty}$. A uniform weak magnetic field of strength $B_{o}$ is applied perpendicular to the surface of the cylinder. The effects of thermal-diffusion, diffusion-thermal, a first order homogenous chemical reaction and radiation on flow, heat and mass transfer are taken into account. A locally orthogonal coordinate system is chosen with origin $\mathrm{O}$, at the lower stagnation point and $\mathrm{X}$ and $\mathrm{Y}$ denoting the distances measured along and perpendicular to the surface respectively. Here "a" is the curvature of the body surface at $\mathrm{O}$. Figure 1 shows the physical model and co-ordinate system.

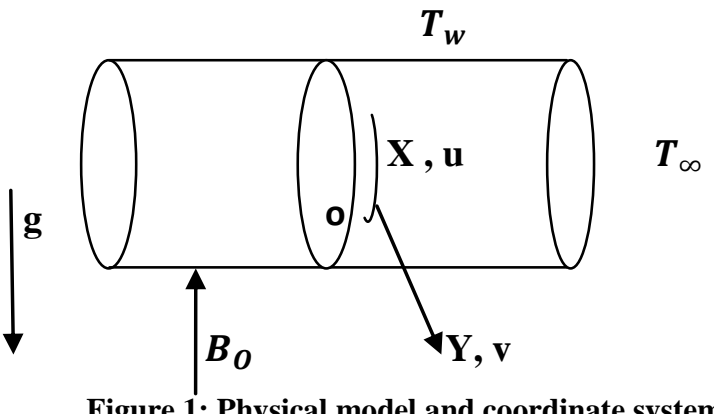

Figure 1: Physical model and coordinate system

It is assumed that the fluid has constant kinematic viscosity and the Boussinesq approximation is taken for the steady laminar boundary flow. The cylinder is considered to be non-electrically conducting and the hall effect has been neglected. The joule heating effect of the fluid is neglected. The fluid is considered to be gray absorbing-emitting radiations but non scattering medium and the Rosseland approximation is used to describe the radiative heat flux in y-direction. The Darcy-Forchheimer model is used to describe the flow in porous media. Under the Boussinesq approximation, the governing equations are given by

$\frac{\partial u}{\partial x}+\frac{\partial v}{\partial y}=0$,

$u \frac{\partial u}{\partial x}+v \frac{\partial u}{\partial y}=g \beta_{T}\left(T-T_{\infty}\right) a x+g \beta_{C}\left(C-C_{\infty}\right) a x+$

$\frac{1}{\rho} \frac{\partial}{\partial y}\left(\mu(T) \frac{\partial u}{\partial y}\right)-\frac{\sigma B_{o}^{2} u}{\rho}-\frac{\mu u}{\rho k^{\prime}}-\frac{b u^{2}}{k^{\prime}}$, $u \frac{\partial T}{\partial x}+v \frac{\partial T}{\partial y}=\frac{1}{\rho C_{p}} \frac{\partial}{\partial y}\left(k(T) \frac{\partial T}{\partial y}\right)-\frac{1}{\rho C_{p}} \frac{\partial q_{r}}{\partial y}+\frac{D k_{T}}{C_{s} C_{p}} \frac{\partial^{2} C}{\partial y^{2}}$

and $u \frac{\partial C}{\partial x}+v \frac{\partial C}{\partial y}=D \frac{\partial^{2} C}{\partial y^{2}}+\frac{D k_{T}}{T_{m}} \frac{\partial^{2} T}{\partial y^{2}}-K_{c}\left(C-C_{\infty}\right)$

where $u$ and $v$ are fluid velocity components in the $x$ and $y$ directions respectively, $g$ is acceleration due to gravity, $C$ and $T$ denotes the concentration and temperature of the fluid, $\rho$ is the density, $\beta_{T}$ is the coefficient of thermal expansion, $\beta_{C}$ is coefficient of concentration expansion, $k^{\prime}$ is the permeability of porous medium, $\sigma$ is the fluid electrical conductivity, $B_{o}$ is the strength of applied magnetic field, $\mu(T)$ is the temperature dependent viscosity of the fluid, $k(T)$ is the temperature dependent thermal conductivity of the fluid, $C_{p}$ is the specific heat at constant pressure, $C_{s}$ is the concentration susceptibility, $q_{r}$ is the radiative heat flux , $D$ is mass diffusivity, $k_{T}$ is thermal diffusion ratio, $T_{m}$ is mean fluid temperature, $K_{c}$ is dimensional of chemical reaction and $b$ is Forchheimer's geometrical (inertial drag) coefficient.

The radiative heat flux $q_{r}$ under Rosseland approximation is given by the expression

$$
q_{r}=-\frac{4 \sigma_{1}}{3 k_{1}} \frac{\partial T^{4}}{\partial y}
$$

where $\sigma_{1}$ is Stefan-Boltzmann constant and $k_{1}$ is the mean absorption coefficient.

It is assumed that temperature differences within the flow are sufficiently small such that $T^{4}$ can be expanded in a Taylor's series about $T_{\infty}$ and after rejecting higher order terms, we have

$$
T^{4}=4 T_{\infty}^{3} T-3 T_{\infty}^{4}
$$

The initial and boundary conditions are

$$
\left.\begin{array}{ll}
u=0, v=0, T=T_{w}, C=C_{w} & \text { at } y=0 \\
u \rightarrow \infty, T \rightarrow T_{\infty}, C \rightarrow C_{\infty} & \text { at } y \rightarrow \infty
\end{array}\right\}
$$

It is assumed that the viscosity $\mu(T)$ and thermal conductivity $k(T)$ varies with temperature as follows:

$$
\begin{aligned}
\mu(T) & =\frac{\mu_{\infty}}{1+\gamma\left(T-T_{\infty}\right)} \\
\text { and } \quad k(T) & =k_{\infty}\left(1+b\left(T-T_{\infty}\right)\right)
\end{aligned}
$$

The similarity transformation is given by

$$
\begin{gathered}
\psi=G r^{\frac{1}{4}} a v x f(\eta), \quad \eta=G r^{\frac{1}{4}} a y, \quad \theta(\eta)=\frac{T-T_{\infty}}{T_{w}-T_{\infty}}, \\
\emptyset(\eta)=\frac{C-C_{\infty}}{C_{w}-C_{\infty}}, G r=\frac{g \beta_{T}\left(T_{w}-T_{\infty}\right)}{a^{3} v^{2}} \text { and } G m=\frac{g \beta_{C}\left(C_{w}-C_{\infty}\right)}{a^{3} v^{2}}
\end{gathered}
$$

where $\psi$ is the stream function, $G r$ is Grashoff number and $\mathrm{Gm}$ is modified Grashoff number.

Substituting the similarity variables from (10) in (2), (3) and (4), we obtain the following differential equations

$$
\begin{gathered}
f^{\prime \prime \prime}=(1+\epsilon \theta)\left[(1+N f) f^{\prime 2}-f f^{\prime \prime}+\frac{\epsilon}{(1+\epsilon \theta)^{2}} \theta^{\prime} f^{\prime \prime}+\right. \\
\left.\frac{1}{\sqrt{G r}}\left\{M+\left(\frac{1}{(1+\epsilon \theta) K}\right)\right\} f^{\prime}-\theta-\frac{G m}{G r} \emptyset\right] \\
\theta^{\prime \prime}=-\frac{3 N}{4+3 N(1+\omega \theta)}\left[\operatorname{Pr} . f \theta^{\prime}+\omega \theta^{\prime 2}+\operatorname{Pr} D_{f} \emptyset^{\prime \prime}\right]
\end{gathered}
$$


$\emptyset^{\prime \prime}+S c f \emptyset^{\prime}+S c S r \theta^{\prime \prime}-\frac{\gamma S c \emptyset}{\sqrt{G r}}=0$

where $\epsilon=\gamma\left(T_{w}-T_{\infty}\right)$ is variable viscosity parameter, $N f=\frac{b x}{k^{\prime}}$ is Forchhiemer inertial porous parameter, $M=\frac{\sigma B_{0}^{2}}{a^{2} \mu_{\infty}}$ is magnetic parameter, $K=k^{\prime} a^{2}$ is porosity parameter, $\omega=b\left(T_{w}-T_{\infty}\right)$ is variable thermal conductivity parameter, $N=\frac{k_{1} k_{\infty}}{4 \sigma_{1} T_{\infty}^{3}}$ is radiation parameter, $\operatorname{Pr}=\frac{\mu_{\infty} C_{p}}{k_{\infty}}$ is Prandtl number, $S c=\frac{v}{D}$ is Schmidt number, $D_{f}=\frac{D k_{T}\left(C_{w}-c_{\infty}\right)}{C_{s} C_{p} v\left(T_{w}-T_{\infty}\right)}$ is Dufour number, $S_{r}=\frac{D k_{T}\left(T_{w}-T_{\infty}\right)}{T_{m} v\left(C_{w}-C_{\infty}\right)}$ is Soret number and $\gamma=\frac{K_{c}}{v a^{2}}$ is chemical reaction parameter.

The initial and boundary conditions (7) becomes

$$
\left.\begin{array}{ll}
f^{\prime}=0, f=0, \theta=1, \emptyset=1 & \text { at } \eta=0 \\
f^{\prime} \rightarrow 0, \theta \rightarrow 0, \emptyset \rightarrow 0 & \text { at } \eta \rightarrow \infty
\end{array}\right\}
$$

\section{RESULTS AND DISCUSSIONS}

The ordinary differential equations (11), (12) and (13) with the corresponding boundary conditions (14) have been solved numerically by using bvp4c solver of MATLAB. From the process of numerical computation, the local Sherwood number which is proportional to $-\emptyset^{\prime}(0)$ is worked out and their numerical values are presented in tabular form. Numerical calculations for $\emptyset^{\prime}$ have been carried out by taking various values of parameters $\epsilon, N f, M, K, \omega, N$, $\operatorname{Pr}, S c, D_{f}, S_{r}$ and $\gamma$.

CaseI: $N f=0.05, M=0.5, K=1, \omega=0.5, N=$ $1, \operatorname{Pr}=0.71, S c=1, D_{f}=0.5, S_{r}=0.5, \gamma=0.2, \epsilon=$ $(0.0,0.5,1.0)$.

CaseII: $\epsilon=0.5, M=0.5, K=1, \omega=0.5, N=$ $1, \operatorname{Pr}=0.71, S c=1, D_{f}=0.5, S_{r}=0.5, \gamma=0.2, N f=$ $(0.05,0.5,1.0)$.

CaseIII: $\epsilon=0.5, N f=0.05, K=1, \omega=0.5, N=$ $1, \operatorname{Pr}=0.71, S c=1, D_{f}=0.5, S_{r}=0.5, \gamma=0.2, M=$ $(0.5,1.0,1.5)$.

CaseIV: $\epsilon=0.5, N f=0.05, M=0.5, \omega=0.5, N=$ $1, \operatorname{Pr}=0.71, S c=1, D_{f}=0.5, S_{r}=0.5, \gamma=0.2, K=$ $(1 \cdot 0,2 \cdot 0,3 \cdot 0)$.

CaseV: $\epsilon=0.5, N f=0.05, M=0.5, K=1, N=$ $1, \operatorname{Pr}=0.71, S c=1, D_{f}=0.5, S_{r}=0.5, \gamma=0.2, \omega=$ $(0.5,1.0,1.5)$.

CaseVI: $\epsilon=0.5, N f=0.05, M=0.5, K=1, \omega=$ $0.5, \operatorname{Pr}=0.71, S c=1, D_{f}=0.5, S_{r}=0.5, \gamma=0.2, N=$ $(0.5,1.0,1.5)$.

CaseVII: $\epsilon=0.5, N f=0.05, M=0.5, K=1, \omega=$ $0.5, N=1, S c=1, D_{f}=0.5, S_{r}=0.5, \gamma=0.2, \operatorname{Pr}=$ $(0.71,1.0,2.0)$.

CaseVIII: $\epsilon=0.5, N f=0.05, M=0.5, K=1, \omega=$ $0.5, N=1, \operatorname{Pr}=0.71, D_{f}=0.5, S_{r}=0.5, \gamma=0.2, S c=$ $(0.5,1.0,1.5)$.

CaseIX: $\epsilon=0.5, N f=0.05, M=0.5, K=1, \omega=$ $0.5, N=1, \operatorname{Pr}=0.71, S c=1, S_{r}=0.5, \gamma=0.2, D_{f}=$ $(0.5,1.0,1.5)$.

CaseX: $\quad \epsilon=0.5, N f=0.05, M=0.5, K=1, \omega=$ $0.5, N=1, \operatorname{Pr}=0.71, S c=1, D_{f}=0.5, \gamma=0.2, S_{r}=$ $(0.5,1.0,1.5)$.
CaseXI: $\epsilon=0.5, N f=0.05, M=0.5, K=1, \omega=0.5, N=$ $1, \operatorname{Pr}=0.71, S c=1, D_{f}=0.5, S_{r}=0.5, \quad \gamma=$ $(0.1,0.2,0.3)$.

Case I:

Figure 2 exhibits concentration profile for various values of variable viscosity parameter $\epsilon$. The value of the concentration is more near the surface of the cylinder than its value at the end of the boundary layer. It depicts that concentration is decreasing as we move away from the surface of the cylinder with increase in the values of parameter $\epsilon$.

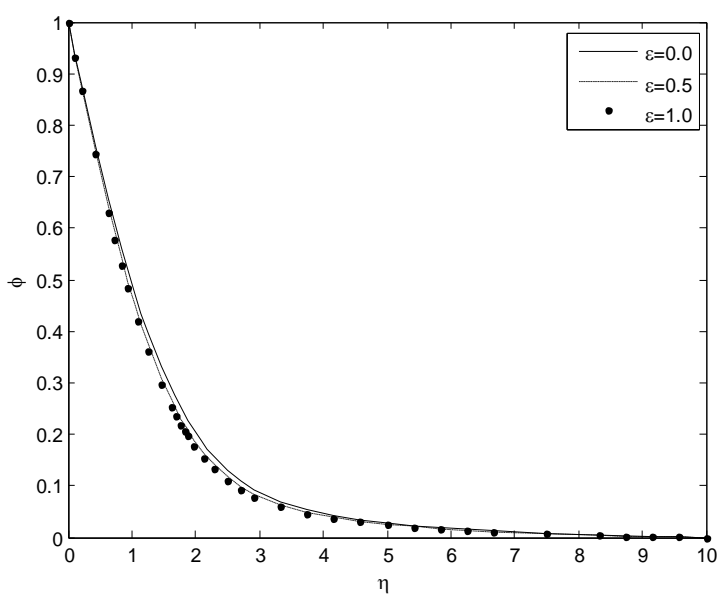

Figure 2: Concentration Profile for $\epsilon=(0.0,0.5,1.0)$ with $N f=0.05, M=0.5, K=1, \omega=0.5, N=$ $1, \operatorname{Pr}=0.71, S c=1, D_{f}=0.5, S_{r}=0.5, \gamma=0.2$.

Case II:

Figure 3 exhibits concentration profile for various values of Forchhiemer inertial porous parameter $N f$. The value of the concentration is more near the surface of the cylinder than its value at the end of the boundary layer. It depicts that concentration is slightly increasing as we move away from the surface of the cylinder with increase in the values of parameter $N f$.

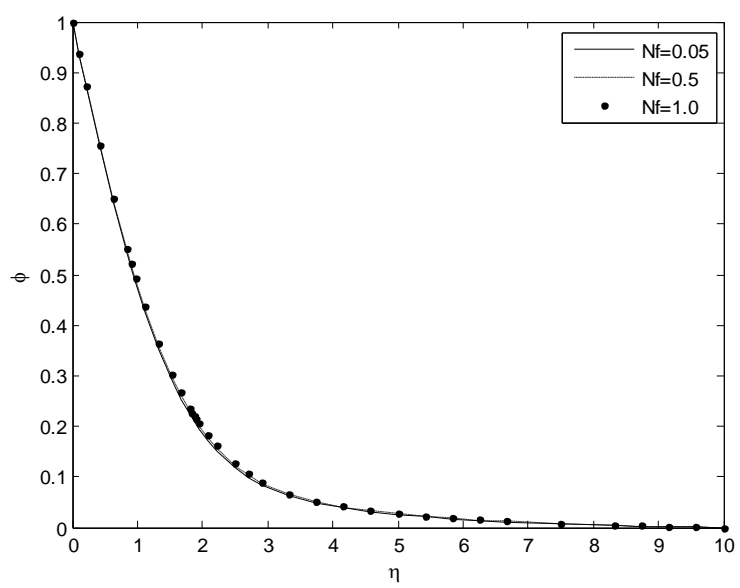

Figure 3: Concentration profile for $\boldsymbol{N} f=(0.05,0.5,1.0)$

with $\epsilon=0.5, M=0.5, K=1, \omega=0.5, N=1$,

$\operatorname{Pr}=0.71, S c=1, D_{f}=0.5, S_{r}=0.5, \gamma=0.2$.

\section{CaseIII:}

Figure 4 exhibits concentration profile for various values of magnetic parameter $M$. The value of the concentration is 
more near the surface of the cylinder than its value at the end of the boundary layer. It depicts that concentration is increasing as we move away from the surface of the cylinder with increase in the values of parameter $M$.

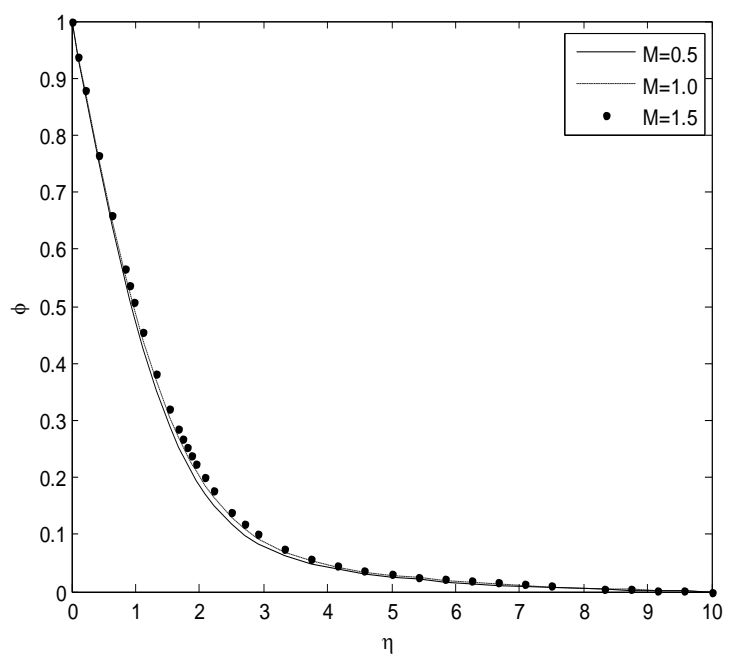

Figure 4: Concentration profile for $M=(0.5,1.0,1.5)$ with $\epsilon=0.5, N f=0.05, K=1, \omega=0.5, N=1$, $\operatorname{Pr}=0.71, S c=1, D_{f}=0.5, S_{r}=0.5, \gamma=0.2$.

\section{Case IV:}

Figure 5 exhibits concentration profile for various values of porosity parameter $K$. The value of the concentration is more near the surface of the cylinder than its value at the end of the boundary layer. It depicts that concentration is increasing as we move away from the surface of the cylinder with increase in the values of parameter $K$.

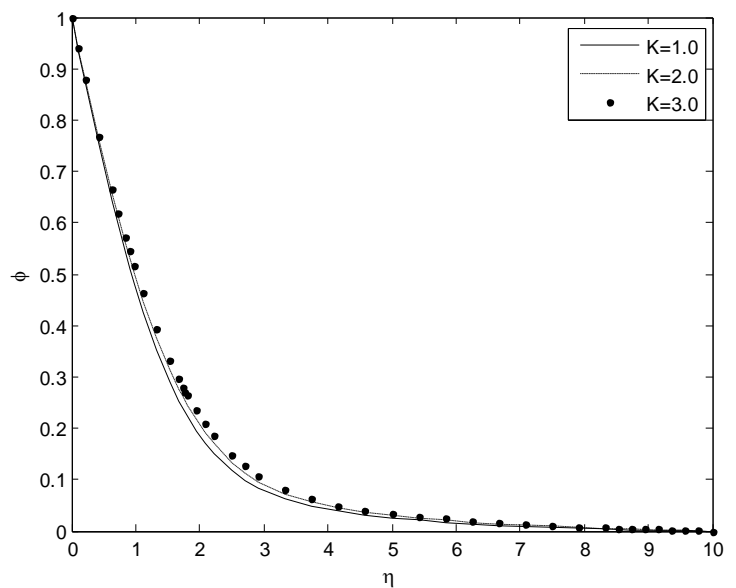

Figure 5: Concentration profile for $K=(1.0,2.0,3.0)$ with $\epsilon=0.5, N f=0.05, M=0.5, \omega=0.5, N=1$, $\operatorname{Pr}=0.71, S c=1, D_{f}=0.5, S_{r}=0.5, \gamma=0.2$.

CaseV:

Figure 6 exhibits concentration profile for various values of variable thermal conductivity parameter $\omega$. The value of the concentration is more near the surface of the cylinder than its value at the end of the boundary layer. It depicts that concentration is decreasing as we move away from the surface of the cylinder with increase in the values of parameter $\omega$.

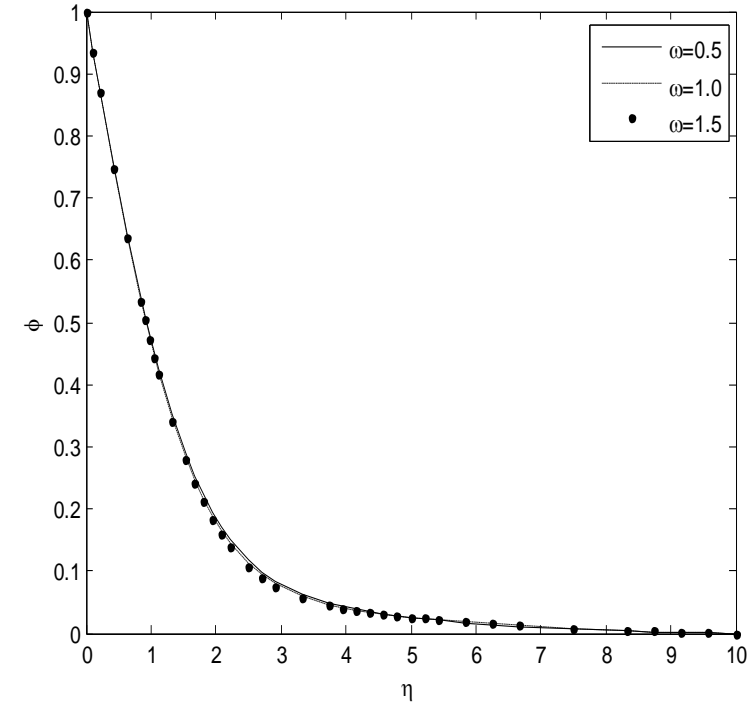

Figure 6: Concentration profile for $\omega=(0.5,1.0,1.5)$ with $\epsilon=0.5, N f=0.05, M=0.5, K=1, N=$

$1, \operatorname{Pr}=0.71, S c=1, D_{f}=0.5, S_{r}=0.5, \gamma=0.2$.

CaseVI:

Figure 7 exhibits concentration profile for various values of radiation parameter $N$. The value of the concentration is more near the surface of the cylinder than its value at the end of the boundary layer. It depicts that concentration is increasing as we move away from the surface of the cylinder with increase in the values of parameter $N$.

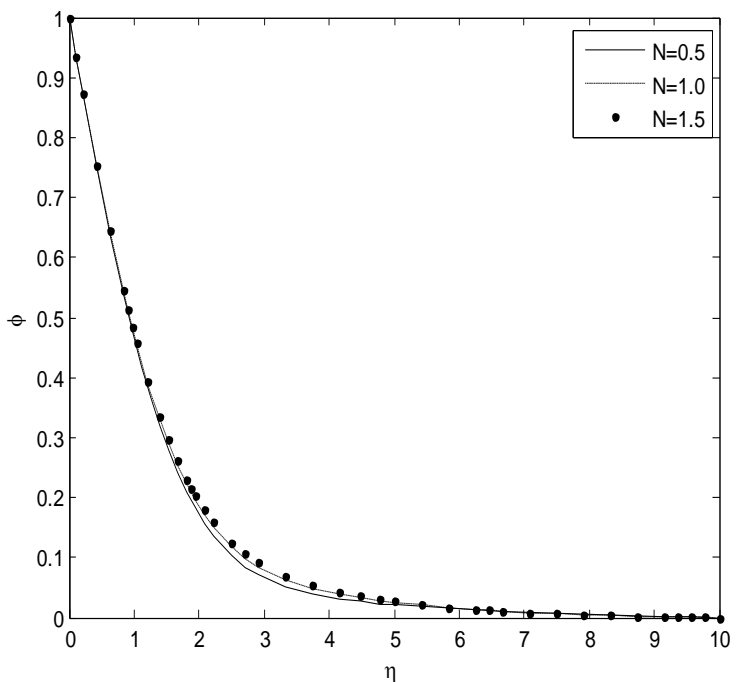

Figure 7:Concentration profile for $N=$

$(0.5,1.0,1.5)$ with $\epsilon=0.5, N f=0.05, M=0.5, K=$ $1, \omega=0.5, \operatorname{Pr}=0.71, S c=1, D_{f}=0.5, S_{r}=0.5$, $\gamma=0.2$

\section{Case VII:}

Figure 8 exhibits concentration profile for various values of Prandtl number $\mathrm{Pr}$. The value of the concentration is more near the surface of the cylinder than its value at the end of the boundary layer. It depicts that concentration increases as we move away from the surface of the cylinder with increase in the values of parameter $\mathrm{Pr}$. 


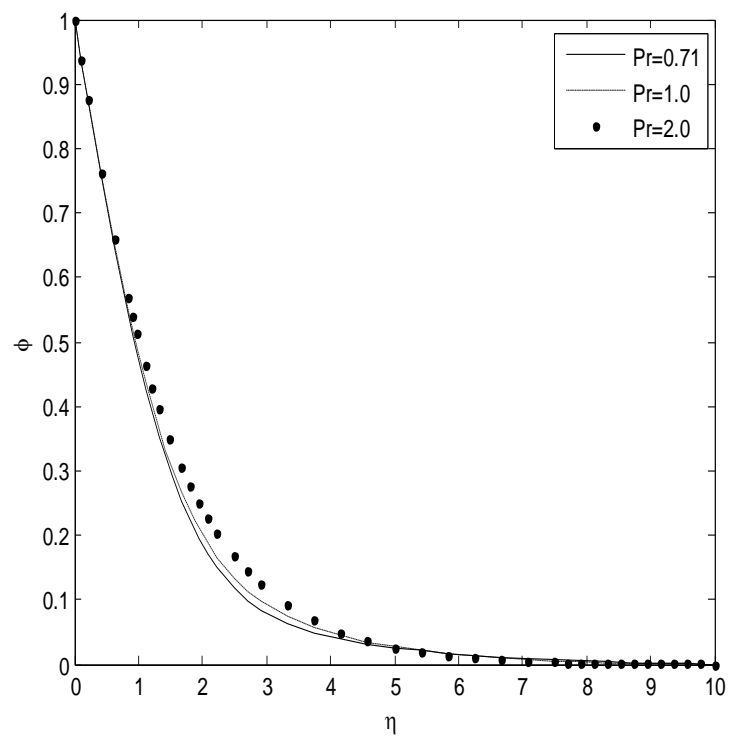

Figure8: Concentration profile for $\operatorname{Pr}=(0.71,1.0,2.0)$ with $\epsilon=0.5, N f=0.05, M=0.5, K=1, \omega=$ $0.5, N=1, S c=1, D_{f}=0.5, S_{r}=0.5, \gamma=0.2$

\section{Case VIII:}

Figure 9 exhibits concentration profile for various values of Schmidt number $S c$. It is noticed that concentration decreases exponentially from its maximum value at the surface of the cylinder to its minimum value at the end of the boundary layer. It is observed that concentration decreases with increase in the values of parameter $S c$.

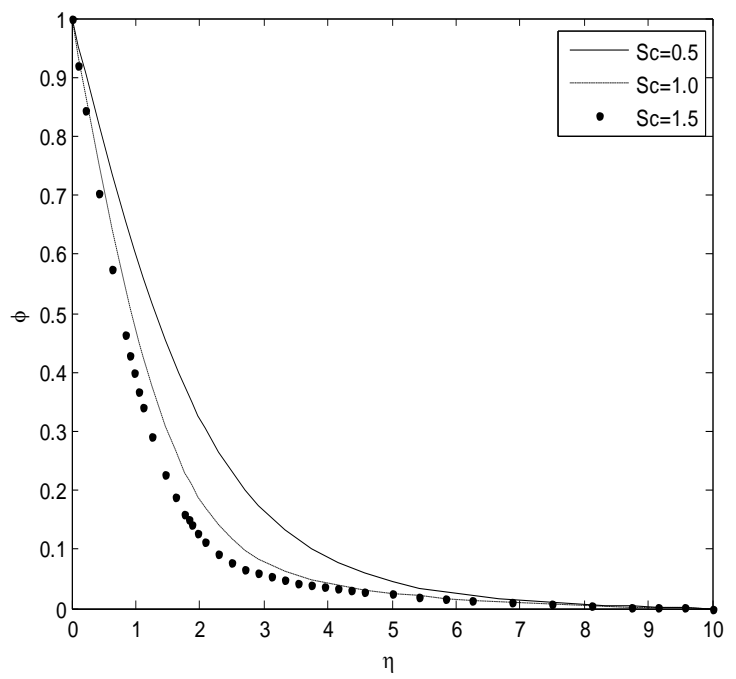

Figure 9: Concentration profile for $S c=(0.5,1.0,1.5)$ with $\epsilon=0.5, N f=0.05, M=0.5, K=1, \omega=0.5, N=$ $1, \operatorname{Pr}=0.71, D_{f}=0.5, S_{r}=0.5, \gamma=0.2$.

\section{Case IX:}

Figure 10 exhibits concentration profile for various values of Dufour number $D_{f}$. The value of the concentration is more near the surface of the cylinder than its value at the end of the boundary layer.It depicts that concentration is decreasing as we move away from the surface of the cylinder with increase in the values of parameter $D_{f}$.

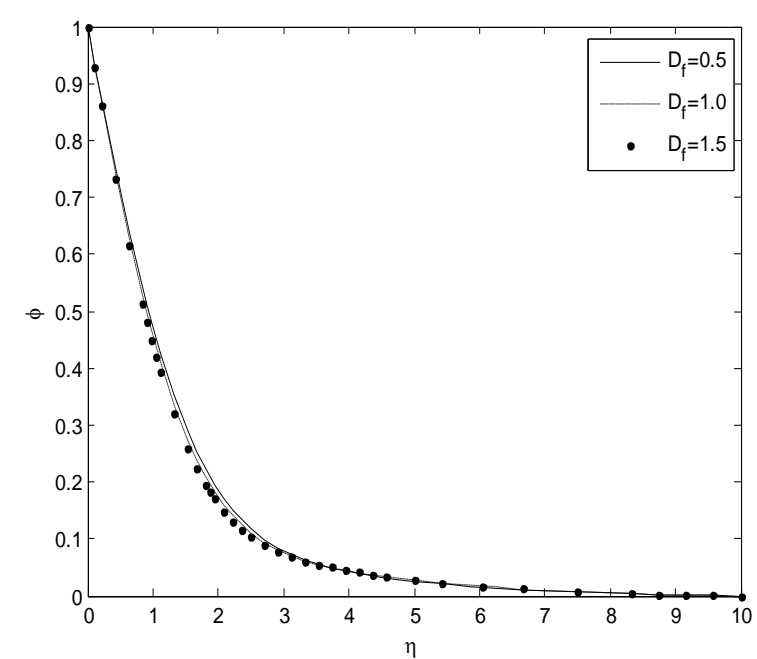

Figure 10: Concentration profile for

$$
D_{f}=(0.5,1.0,1.5) \text { with } \epsilon=0.5, N f=0.05, M=
$$$$
0.5, K=1, \omega=0.5, N=1, P r=0.71, S c=1, S_{r}=
$$$$
0.5, \gamma=0.2 \text {. }
$$

\section{CaseX:}

Figure 11 exhibits concentration profile for various values of Soret number $S_{r}$. The value of the concentration is more near the surface of the cylinder than its value at the end of the boundary layer. It depicts that concentration increases as we move away from the surface of the cylinder with increase in the values of parameter $S_{r}$.

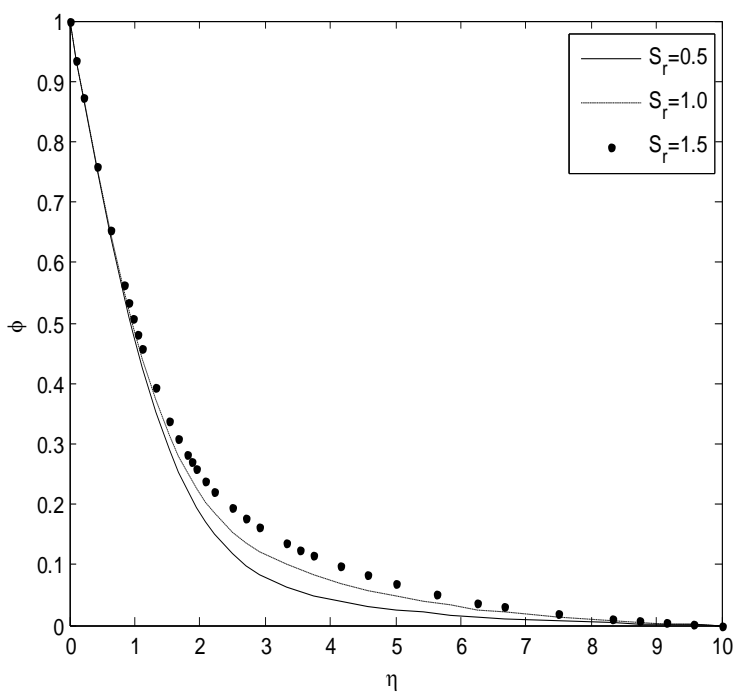

Figure 11: Concentration profile for $S_{r}=(0.5,1.0,1.5)$ with $\epsilon=0.5, N f=0.05, M=05, K=1, \omega=0.5, N=$ $1, \operatorname{Pr}=0.71, S c=1, D_{f}=0.5, \gamma=0.2$.

Case XI:

Figure 12 exhibits concentration profile for various values of chemical reaction parameter $\gamma$. It is noticed that concentration decreases exponentially from its maximum value at the surface of the cylinder to its minimum value at the end of the boundary layer.It is observed that concentration decreases with increase in the values of parameter $\gamma$. 


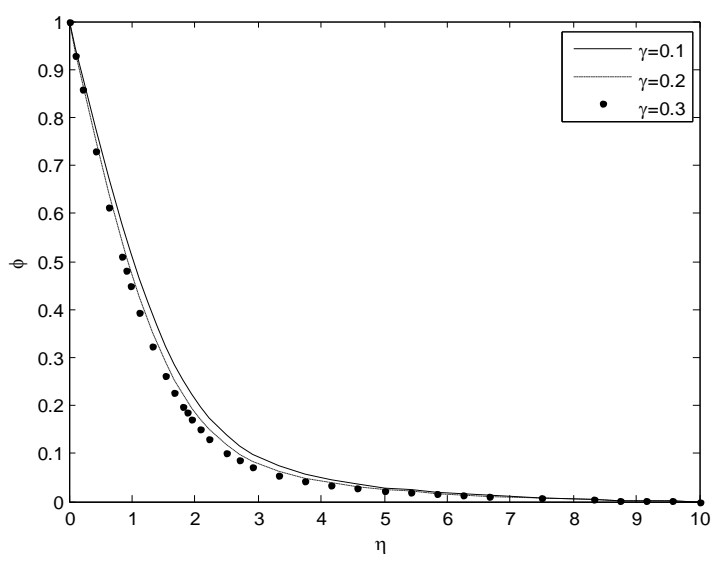

Figure 12: Concentration profile for $\gamma=(0.1,0.2,0.3)$ with $\epsilon=0.5, N f=0.05, M=0.5, K=1, \omega=0.5, N=$ $1, P r=0.71, S c=1, D_{f}=0.5, S_{r}=0.5$.

Table 1 : The values of rate of mass transfer in terms of local Sherwood number $-\emptyset^{\prime}(0)$ for selected values of $\epsilon, N f, M, K, \omega, N, \operatorname{Pr}, S c, D_{f}, S_{r}, \gamma$ taking $G r=G m=1$.

\begin{tabular}{|c|c|c|c|c|c|c|c|c|c|c|c|}
\hline$\epsilon$ & $N f$ & $\boldsymbol{M}$ & $K$ & $\boldsymbol{\omega}$ & $\boldsymbol{N}$ & $P r$ & $S c$ & $D_{f}$ & $S_{r}$ & $\gamma$ & $-\emptyset^{\prime}(0$ \\
\hline $\begin{array}{l}0 . \\
0\end{array}$ & $\begin{array}{l}0 . \\
05\end{array}$ & $\begin{array}{l}0 . \\
5\end{array}$ & 1 & $\begin{array}{l}0 . \\
5\end{array}$ & 1 & $\begin{array}{l}0 . \\
71\end{array}$ & 1 & $\begin{array}{l}0 . \\
5\end{array}$ & $\begin{array}{l}0 . \\
5\end{array}$ & $\begin{array}{l}0 . \\
2\end{array}$ & $\begin{array}{l}0.61 \\
49\end{array}$ \\
\hline $\begin{array}{l}0 . \\
5\end{array}$ & $\begin{array}{l}0 . \\
05\end{array}$ & $\begin{array}{l}0 . \\
5\end{array}$ & 1 & $\begin{array}{l}0 . \\
5\end{array}$ & 1 & $\begin{array}{l}0 . \\
71\end{array}$ & 1 & $\begin{array}{l}0 . \\
5\end{array}$ & $\begin{array}{l}0 . \\
5\end{array}$ & $\begin{array}{l}0 . \\
2\end{array}$ & $\begin{array}{l}0.63 \\
97\end{array}$ \\
\hline $\begin{array}{l}1 . \\
0\end{array}$ & $\begin{array}{l}0 . \\
05\end{array}$ & $\begin{array}{l}0 . \\
5\end{array}$ & 1 & $\begin{array}{l}0 . \\
5\end{array}$ & 1 & $\begin{array}{l}0 . \\
71\end{array}$ & 1 & $\begin{array}{l}0 . \\
5\end{array}$ & $\begin{array}{l}0 . \\
5\end{array}$ & $\begin{array}{l}0 . \\
2\end{array}$ & $\begin{array}{l}0.65 \\
75\end{array}$ \\
\hline $\begin{array}{l}0 . \\
5\end{array}$ & $\begin{array}{l}0 . \\
05\end{array}$ & $\begin{array}{l}0 . \\
5\end{array}$ & 1 & $\begin{array}{l}0 . \\
5\end{array}$ & 1 & $\begin{array}{l}0 . \\
71\end{array}$ & 1 & $\begin{array}{l}0 . \\
5\end{array}$ & $\begin{array}{l}0 . \\
5\end{array}$ & $\begin{array}{l}0 . \\
2\end{array}$ & $\begin{array}{l}0.63 \\
97\end{array}$ \\
\hline $\begin{array}{l}0 . \\
5\end{array}$ & $\begin{array}{l}0 . \\
5\end{array}$ & $\begin{array}{l}0 . \\
5\end{array}$ & 1 & $\begin{array}{l}0 . \\
5\end{array}$ & 1 & $\begin{array}{l}0 . \\
71\end{array}$ & 1 & $\begin{array}{l}0 . \\
5\end{array}$ & $\begin{array}{l}0 . \\
5\end{array}$ & $\begin{array}{l}0 . \\
2\end{array}$ & $\begin{array}{l}0.63 \\
28\end{array}$ \\
\hline $\begin{array}{l}0 . \\
5\end{array}$ & $\begin{array}{l}1 . \\
0\end{array}$ & $\begin{array}{l}0 . \\
5\end{array}$ & 1 & $\begin{array}{l}0 . \\
5\end{array}$ & 1 & $\begin{array}{l}0 . \\
71\end{array}$ & 1 & $\begin{array}{l}0 . \\
5\end{array}$ & $\begin{array}{l}0 . \\
5\end{array}$ & $\begin{array}{l}0 . \\
2\end{array}$ & $\begin{array}{l}0.62 \\
63\end{array}$ \\
\hline $\begin{array}{l}0 . \\
5\end{array}$ & $\begin{array}{l}0 . \\
05\end{array}$ & $\begin{array}{l}0 . \\
5\end{array}$ & 1 & $\begin{array}{l}0 . \\
5\end{array}$ & 1 & $\begin{array}{l}0 . \\
71\end{array}$ & 1 & $\begin{array}{l}0 . \\
5\end{array}$ & $\begin{array}{l}0 . \\
5\end{array}$ & $\begin{array}{l}0 . \\
2\end{array}$ & $\begin{array}{l}0.63 \\
97\end{array}$ \\
\hline $\begin{array}{l}0 . \\
5\end{array}$ & $\begin{array}{l}0 . \\
05\end{array}$ & $\begin{array}{l}1 . \\
0\end{array}$ & 1 & $\begin{array}{l}0 . \\
5\end{array}$ & 1 & $\begin{array}{l}0 . \\
71\end{array}$ & 1 & $\begin{array}{l}0 . \\
5\end{array}$ & $\begin{array}{l}0 . \\
5\end{array}$ & $\begin{array}{l}0 . \\
2\end{array}$ & $\begin{array}{l}0.62 \\
29\end{array}$ \\
\hline $\begin{array}{l}0 . \\
5\end{array}$ & $\begin{array}{l}0 . \\
05\end{array}$ & $\begin{array}{l}1 . \\
5\end{array}$ & 1 & $\begin{array}{l}0 . \\
5\end{array}$ & 1 & $\begin{array}{l}0 . \\
71\end{array}$ & 1 & $\begin{array}{l}0 . \\
5\end{array}$ & $\begin{array}{l}0 . \\
5\end{array}$ & $\begin{array}{l}0 . \\
2\end{array}$ & $\begin{array}{l}0.60 \\
88\end{array}$ \\
\hline $\begin{array}{l}0 . \\
5\end{array}$ & $\begin{array}{l}0 . \\
05\end{array}$ & $\begin{array}{l}0 . \\
5\end{array}$ & 1 & $\begin{array}{l}0 . \\
5\end{array}$ & 1 & $\begin{array}{l}0 . \\
71\end{array}$ & 1 & $\begin{array}{l}0 . \\
5\end{array}$ & $\begin{array}{l}0 . \\
5\end{array}$ & $\begin{array}{l}0 . \\
2\end{array}$ & $\begin{array}{l}0.63 \\
97\end{array}$ \\
\hline $\begin{array}{l}0 . \\
5\end{array}$ & $\begin{array}{l}0 . \\
05\end{array}$ & $\begin{array}{l}0 . \\
5\end{array}$ & 2 & $\begin{array}{l}0 . \\
5\end{array}$ & 1 & $\begin{array}{l}0 . \\
71\end{array}$ & 1 & $\begin{array}{l}0 . \\
5\end{array}$ & $\begin{array}{l}0 . \\
5\end{array}$ & $\begin{array}{l}0 . \\
2\end{array}$ & $\begin{array}{l}0.61 \\
66\end{array}$ \\
\hline $\begin{array}{l}0 . \\
5\end{array}$ & $\begin{array}{l}0 . \\
05\end{array}$ & $\begin{array}{l}0 . \\
5\end{array}$ & 3 & $\begin{array}{l}0 . \\
5\end{array}$ & 1 & $\begin{array}{l}0 . \\
71\end{array}$ & 1 & $\begin{array}{l}0 . \\
5\end{array}$ & $\begin{array}{l}0 . \\
5\end{array}$ & $\begin{array}{l}0 . \\
2\end{array}$ & $\begin{array}{l}0.59 \\
87\end{array}$ \\
\hline $\begin{array}{l}0 . \\
5\end{array}$ & $\begin{array}{l}0 . \\
05\end{array}$ & $\begin{array}{l}0 . \\
5\end{array}$ & 1 & $\begin{array}{l}0 . \\
5\end{array}$ & 1 & $\begin{array}{l}0 . \\
71\end{array}$ & 1 & $\begin{array}{l}0 . \\
5\end{array}$ & $\begin{array}{l}0 . \\
5\end{array}$ & $\begin{array}{l}0 . \\
2\end{array}$ & $\begin{array}{l}0.63 \\
97\end{array}$ \\
\hline
\end{tabular}

\begin{tabular}{|c|c|c|c|c|c|c|c|c|c|c|c|}
\hline $\begin{array}{l}0 . \\
5\end{array}$ & $\begin{array}{l}0 . \\
05\end{array}$ & $\begin{array}{l}0 . \\
5\end{array}$ & 1 & $\begin{array}{l}1 . \\
0\end{array}$ & 1 & $\begin{array}{l}0 . \\
71\end{array}$ & 1 & $\begin{array}{l}0 . \\
5\end{array}$ & $\begin{array}{l}0 . \\
5\end{array}$ & $\begin{array}{l}0 . \\
2\end{array}$ & $\begin{array}{l}0.64 \\
45\end{array}$ \\
\hline $\begin{array}{l}0 . \\
5\end{array}$ & $\begin{array}{l}0 . \\
05\end{array}$ & $\begin{array}{l}0 . \\
5\end{array}$ & 1 & $\begin{array}{l}1 . \\
5\end{array}$ & 1 & $\begin{array}{l}0 . \\
71\end{array}$ & 1 & $\begin{array}{l}0 . \\
5\end{array}$ & $\begin{array}{l}0 . \\
5\end{array}$ & $\begin{array}{l}0 . \\
2\end{array}$ & $\begin{array}{l}0.64 \\
80\end{array}$ \\
\hline $\begin{array}{l}0 . \\
5\end{array}$ & $\begin{array}{l}0 . \\
05\end{array}$ & $\begin{array}{l}0 . \\
5\end{array}$ & 1 & $\begin{array}{l}0 . \\
5\end{array}$ & $\begin{array}{l}0 . \\
5\end{array}$ & $\begin{array}{l}0 . \\
71\end{array}$ & 1 & $\begin{array}{l}0 . \\
5\end{array}$ & $\begin{array}{l}0 . \\
5\end{array}$ & $\begin{array}{l}0 . \\
2\end{array}$ & $\begin{array}{l}0.64 \\
49\end{array}$ \\
\hline $\begin{array}{l}0 . \\
5\end{array}$ & $\begin{array}{l}0 . \\
05\end{array}$ & $\begin{array}{l}0 . \\
5\end{array}$ & 1 & $\begin{array}{l}0 . \\
5\end{array}$ & $\begin{array}{l}1 . \\
0\end{array}$ & $\begin{array}{l}0 . \\
71\end{array}$ & 1 & $\begin{array}{l}0 . \\
5\end{array}$ & $\begin{array}{l}0 . \\
5\end{array}$ & $\begin{array}{l}0 . \\
2\end{array}$ & $\begin{array}{l}0.63 \\
97\end{array}$ \\
\hline $\begin{array}{l}0 . \\
5\end{array}$ & $\begin{array}{l}0 . \\
05\end{array}$ & $\begin{array}{l}0 . \\
5\end{array}$ & 1 & $\begin{array}{l}0 . \\
5\end{array}$ & $\begin{array}{l}1 . \\
5\end{array}$ & $\begin{array}{l}0 . \\
71\end{array}$ & 1 & $\begin{array}{l}0 . \\
5\end{array}$ & $\begin{array}{l}0 . \\
5\end{array}$ & $\begin{array}{l}0 . \\
2\end{array}$ & $\begin{array}{l}0.63 \\
72\end{array}$ \\
\hline $\begin{array}{l}0 . \\
5\end{array}$ & $\begin{array}{l}0 . \\
05\end{array}$ & $\begin{array}{l}0 . \\
5\end{array}$ & 1 & $\begin{array}{l}0 . \\
5\end{array}$ & 1 & $\begin{array}{l}0 . \\
71\end{array}$ & 1 & $\begin{array}{l}0 . \\
5\end{array}$ & $\begin{array}{l}0 . \\
5\end{array}$ & $\begin{array}{l}0 . \\
2\end{array}$ & $\begin{array}{l}0.63 \\
97\end{array}$ \\
\hline $\begin{array}{l}0 . \\
5\end{array}$ & $\begin{array}{l}0 . \\
05\end{array}$ & $\begin{array}{l}0 . \\
5\end{array}$ & 1 & $\begin{array}{l}0 . \\
5\end{array}$ & 1 & $\begin{array}{l}1 . \\
0\end{array}$ & 1 & $\begin{array}{l}0 . \\
5\end{array}$ & $\begin{array}{l}0 . \\
5\end{array}$ & $\begin{array}{l}0 . \\
2\end{array}$ & $\begin{array}{l}0.63 \\
32\end{array}$ \\
\hline $\begin{array}{l}0 . \\
5\end{array}$ & $\begin{array}{l}0 . \\
05\end{array}$ & $\begin{array}{l}0 . \\
5\end{array}$ & 1 & $\begin{array}{l}0 . \\
5\end{array}$ & 1 & $\begin{array}{l}2 . \\
0\end{array}$ & 1 & $\begin{array}{l}0 . \\
5\end{array}$ & $\begin{array}{l}0 . \\
5\end{array}$ & $\begin{array}{l}0 . \\
2\end{array}$ & $\begin{array}{l}0.61 \\
86\end{array}$ \\
\hline $\begin{array}{l}0 . \\
5\end{array}$ & $\begin{array}{l}0 . \\
05\end{array}$ & $\begin{array}{l}0 . \\
5\end{array}$ & 1 & $\begin{array}{l}0 . \\
5\end{array}$ & 1 & $\begin{array}{l}0 . \\
71\end{array}$ & $\begin{array}{l}0 . \\
5\end{array}$ & $\begin{array}{l}0 . \\
5\end{array}$ & $\begin{array}{l}0 . \\
5\end{array}$ & $\begin{array}{l}0 . \\
2\end{array}$ & $\begin{array}{l}0.45 \\
53\end{array}$ \\
\hline $\begin{array}{l}0 . \\
5\end{array}$ & $\begin{array}{l}0 . \\
05\end{array}$ & $\begin{array}{l}0 . \\
5\end{array}$ & 1 & $\begin{array}{l}0 . \\
5\end{array}$ & 1 & $\begin{array}{l}0 . \\
71\end{array}$ & $\begin{array}{l}1 . \\
0\end{array}$ & $\begin{array}{l}0 . \\
5\end{array}$ & $\begin{array}{l}0 . \\
5\end{array}$ & $\begin{array}{l}0 . \\
2\end{array}$ & $\begin{array}{l}0.63 \\
97\end{array}$ \\
\hline $\begin{array}{l}0 . \\
5\end{array}$ & $\begin{array}{l}0 . \\
05\end{array}$ & $\begin{array}{l}0 . \\
5\end{array}$ & 1 & $\begin{array}{l}0 . \\
5\end{array}$ & 1 & $\begin{array}{l}0 . \\
71\end{array}$ & $\begin{array}{l}1 . \\
5\end{array}$ & $\begin{array}{l}0 . \\
5\end{array}$ & $\begin{array}{l}0 . \\
5\end{array}$ & $\begin{array}{l}0 . \\
2\end{array}$ & $\begin{array}{l}0.78 \\
18\end{array}$ \\
\hline $\begin{array}{l}0 . \\
5\end{array}$ & $\begin{array}{l}0 . \\
05\end{array}$ & $\begin{array}{l}0 . \\
5\end{array}$ & 1 & $\begin{array}{l}0 . \\
5\end{array}$ & 1 & $\begin{array}{l}0 . \\
71\end{array}$ & 1 & $\begin{array}{l}0 . \\
5\end{array}$ & $\begin{array}{l}0 . \\
5\end{array}$ & $\begin{array}{l}0 . \\
2\end{array}$ & $\begin{array}{l}0.63 \\
97\end{array}$ \\
\hline $\begin{array}{l}0 . \\
5\end{array}$ & $\begin{array}{l}0 . \\
05\end{array}$ & $\begin{array}{l}0 . \\
5\end{array}$ & 1 & $\begin{array}{l}0 . \\
5\end{array}$ & 1 & $\begin{array}{l}0 . \\
71\end{array}$ & 1 & $\begin{array}{l}1 . \\
0\end{array}$ & $\begin{array}{l}0 . \\
5\end{array}$ & $\begin{array}{l}0 . \\
2\end{array}$ & $\begin{array}{l}0.66 \\
32\end{array}$ \\
\hline $\begin{array}{l}0 . \\
5\end{array}$ & $\begin{array}{l}0 . \\
05\end{array}$ & $\begin{array}{l}0 . \\
5\end{array}$ & 1 & $\begin{array}{l}0 . \\
5\end{array}$ & 1 & $\begin{array}{l}0 . \\
71\end{array}$ & 1 & $\begin{array}{l}1 . \\
5\end{array}$ & $\begin{array}{l}0 . \\
5\end{array}$ & $\begin{array}{l}0 . \\
2\end{array}$ & $\begin{array}{l}0.68 \\
90\end{array}$ \\
\hline $\begin{array}{l}0 . \\
5\end{array}$ & $\begin{array}{l}0 . \\
05\end{array}$ & $\begin{array}{l}0 . \\
5\end{array}$ & 1 & $\begin{array}{l}0 . \\
5\end{array}$ & 1 & $\begin{array}{l}0 . \\
71\end{array}$ & 1 & $\begin{array}{l}0 . \\
5\end{array}$ & $\begin{array}{l}0 . \\
5\end{array}$ & $\begin{array}{l}0 . \\
2\end{array}$ & $\begin{array}{l}0.63 \\
97\end{array}$ \\
\hline $\begin{array}{l}0 . \\
5\end{array}$ & $\begin{array}{l}0 . \\
05\end{array}$ & $\begin{array}{l}0 . \\
5\end{array}$ & 1 & $\begin{array}{l}0 . \\
5\end{array}$ & 1 & $\begin{array}{l}0 . \\
71\end{array}$ & 1 & $\begin{array}{l}0 . \\
5\end{array}$ & $\begin{array}{l}1 . \\
0\end{array}$ & $\begin{array}{l}0 . \\
2\end{array}$ & $\begin{array}{l}0.63 \\
51\end{array}$ \\
\hline $\begin{array}{l}0 . \\
5\end{array}$ & $\begin{array}{l}0 . \\
05\end{array}$ & $\begin{array}{l}0 . \\
5\end{array}$ & 1 & $\begin{array}{l}0 . \\
5\end{array}$ & 1 & $\begin{array}{l}0 . \\
71\end{array}$ & 1 & $\begin{array}{l}0 . \\
5\end{array}$ & $\begin{array}{l}1 . \\
5\end{array}$ & $\begin{array}{l}0 . \\
2\end{array}$ & $\begin{array}{l}0.63 \\
08\end{array}$ \\
\hline $\begin{array}{l}0 . \\
5\end{array}$ & $\begin{array}{l}0 . \\
05\end{array}$ & $\begin{array}{l}0 . \\
5\end{array}$ & 1 & $\begin{array}{l}0 . \\
5\end{array}$ & 1 & $\begin{array}{l}0 . \\
71\end{array}$ & 1 & $\begin{array}{l}0 . \\
5\end{array}$ & $\begin{array}{l}0 . \\
5\end{array}$ & $\begin{array}{l}0 . \\
1\end{array}$ & $\begin{array}{l}0.55 \\
99\end{array}$ \\
\hline $\begin{array}{l}0 . \\
5\end{array}$ & $\begin{array}{l}0 . \\
05\end{array}$ & $\begin{array}{l}0 . \\
5\end{array}$ & 1 & $\begin{array}{l}0 . \\
5\end{array}$ & 1 & $\begin{array}{l}0 . \\
71\end{array}$ & 1 & $\begin{array}{l}0 . \\
5\end{array}$ & $\begin{array}{l}0 . \\
5\end{array}$ & $\begin{array}{l}0 . \\
2\end{array}$ & $\begin{array}{l}0.63 \\
77\end{array}$ \\
\hline $\begin{array}{l}0 . \\
5\end{array}$ & $\begin{array}{l}0 . \\
05\end{array}$ & $\begin{array}{l}0 . \\
5\end{array}$ & 1 & $\begin{array}{l}0 . \\
5\end{array}$ & 1 & $\begin{array}{l}0 . \\
71\end{array}$ & 1 & $\begin{array}{l}0 . \\
5\end{array}$ & $\begin{array}{l}0 . \\
5\end{array}$ & $\begin{array}{l}0 . \\
3\end{array}$ & $\begin{array}{l}0.71 \\
22\end{array}$ \\
\hline
\end{tabular}

\section{CONCLUSIONS}

In this work, chemical reaction, radiation, thermal-diffusion and diffusion-thermo effects on MHD flow, heat and mass transfer due to an isothermal horizontal circular cylinder in a Porous medium using the Darcy-Forchheimer model has been investigated. From our investigation as obvious from table 1, it can be concluded that the rate of mass transfer decreases in 
magnitude with increase in Forchhiemer inertial porous parameter, magnetic field, porosity parameter , radiation parameter, Prandtl number and Soret number but increases in magnitude with increase in variable viscosity parameter, variable thermal conductivity parameter, Schmidt number, Dufour number and chemical reaction parameter. So, further investigation of the problem can be done by considering heat generation or absorption case.

\section{REFERENCES}

[1] Hossain, M. A., Kabir, S., and Rees, D. A. S. (2002). Natural convection of fluid with temperature dependent viscosity from heated vertical wavy surface, ZAMP, Vol. 53, pp. 48-52.

[2] Nazar, R., Amin N., and Pop, I. (2002). Free convection boundary layer on an isothermal horizontal circular cylinder in a micro-polar fluid. 12th international conference Heat Transfer.

[3] Hossain, M. A., Kutubuddin , M., and Pop, I. (1999). Radiation-conduction interaction on mixed convection past a horizontal circular cylinder. Int $\mathrm{J}$ Heat Mass transfer, Vol. 35, pp.307-314.

[4] Kafoussius, N. G., and Rees, D. A. S. (1998). Numerical study of the combined free and forced convective laminar boundary layer flow past a vertical isothermal flat plate with temperature dependent viscosity. Acta Mech, Vol. 127, pp. 39-50.

[5] Mehta, N. K., and Sood, S. (1992). Transient free convection flow with temperature dependent viscosity in a fluid saturated porous media. Int J Eng Sci, Vol. 30, pp. 1083-1087.

[6] Harris, S. D., and. Ingham, D. B. (2000). "Transient free convection near the lower stagnation point of a cylindrical surface subjected to a sudden change in surface temperature". Int Comm. Heat Transfer, Vol. 27, pp. 1091-1100.

[7] Sekhar, T. V. S., Sivakumar, R., Kumar, H., and Ravikumar,T.V.R. (2007). Effect of aligned magnetic field on the steady viscous flow past a circular cylinder. App Math Model, Vol. 31, pp. 130-139.

[8] Merkin, J. H. (1977) Mixed convection boundary layer on an isothermal horizontal circular cylinder". Int J Heat Mass Transfer, Vol. 20, pp. 73-77.

[9] Molla, M., Hossain, A., and Reddy, G.R.S. (2005). Natural convection flow from an isothermal horizontal circular cylinder with temperature dependent viscosity. Heat Mass Transfer, Vol. 41, pp. 594-598.

[10] Takhar, H. S., Chamka A. J., and Nath, G. (2000). Combined heat and mass transfer along a vertical moving cylinder with a free stream. Heat Mass Transfer, Vol. 36, No.3 , pp. 237-246.

[11] Bhargava, R., Takhar, H. S., Rawat, S., Beg, T.A., and Beg, O.A. (2007). Finite element solutions for nonNewtonaian pulsalite flow in a non-darcian porous medium conduit. Nonlinear Analysis: Modelling and Control, Vol. 12, No. 3, pp 317-327.

[12] Elgazery, N.S. (2008). Transient analysis of heat and mass transfer by natural convection in power law fluid past a vertical plate immersed in a porous medium. Applications and Applied Mathematics, Vol. 3, No. 2, pp. 267-285.

[13] Rashad, A.M. (2009). Perturbation analysis of radiative effect on free convection flow in the presence of pressure work and viscous dissipation. Communication in nonlinear sciences and numerical simulation, Vol. 14, pp. 140-153.

[14] Deka, R. K, and Paul, A. (2011). Transient free convective flow past an infinite vertical cylinder with heat and mass transfer, Applied Mathematical Sciences, Vol. 5, No. 79, pp. 3903-3916.

[15] Ganeswar Reddy, M., and Bhaskar Reddy, N. (2009). Radiation and mass transfer effects on unsteady MHD free convective flow of an incompressible viscous fluid past a moving vertical cylinder, Theoretical applied Mechanics, Vol. 36, No. 3, pp. 239-260.

[16] Yih, K. A. (1999). Radiation effect on natural media International Communications in Heat and Mass Transfer, Vol. 26, No.2, pp. 259-267.

[17] Chamkha, A. J., and Ben-Nakhi, A. (2008). MHD mixed convection-radiation interaction along a permeable surface immersed in a porous medium in the presence of Soret and Dufour's Effects. Heat and Mass Transfer, Vol. 44, No. 7 , pp. $845-856$

[18] Kandasami, R., Periasami, K., and Prabhu Sivagnana, K. K. (2005). Chemical reaction, heat and mass transfer on MHD flow over a vertical stretching surface with heat source and thermal stratification effects. International Journal of Heat and Mass Transfer, Vol. 48, No. 21, pp. 4557- 4561

[19] Sharma, B. R., and Nath, K. (2013). Effects of Heat Generation, Thermal Diffusion, Magnetic Field and Chemical Reaction on De-mixing of a Binary Fluid Mixture. Journal of Applied Mathematics and Fluid Mechanics, Vol. 5, No.1, pp. 23-31

[20] Ibrahim, F. S., Elaiw, A. M., and Bakr, A. A. (2008), Effect of the chemical reaction and radiation absorption on the unsteady MHD free convection flow past a semi infinite vertical permeable moving plate with heat source and suction., Communications in Nonlinear Science and Numerical Simulation. Vol. 13, No.6, pp. 1056-1066.

[21] Sharma, B.R., and Konwar, H. (2015). MHD flow, heat and mass transfer due to axially moving cylinder in presence of thermal diffusion, radiation and chemical reactions in a binary fluid mixture. International Journal of Computer Applications. Vol. 110, No. 15, pp. 52-59.

[22] Uddin, Z., and Kumar, M. (2011). MHD Heat and Mass Transfer Free Convection Flow Near the Lower Stagnation Point of an Isothermal Cylinder Imbedded in Porous Domain with the Presence of Radiation. Jordam Journal of Mechanical and Industrial Engineering. Vol 5, No. 2, pp. 133-138

[23] El-Kabeir, S,M,M, (2011). Soret and Dufour effects on heat and mass transfer due to a stretching cylinder saturated porous medium with chemically-reactive species. Latin American Applied Research Vol. 41, No. 4, pp. 331-337. 